\title{
Overexpression of S-adenosylhomocysteine hydrolase and down-regulation of prohibitin and c-Myc binding protein in the human esophageal squamous cell line HEEC exposed to $\mathrm{N}$-nitrosomethylbenzylamine
}

\author{
YONGEN XIE, ENJIE TANG, BIXUAN REN and LI FENG
}

Institute of Immunology and Molecular Biology, North Sichuan Medical College, Sichuan, Nanchong 637007, P.R.China

Received January 8, 2010; Accepted March 10, 2010

DOI: $10.3892 / \mathrm{mmr}_{-} 00000288$

\begin{abstract}
Numerous studies have shown that N-nitrosamines and their precursors are probable etiological factors for esophageal cancer. Certain N-nitrosamines have been shown to induce esophageal cancer in animal models. However, the molecular mechanisms by which N-nitrosamines promote esophageal carcinogenesis remain poorly understood. In this study, we compared the protein expression profiles of the human esophageal squamous cell line HEEC before and after treatment with various concentrations of N-nitrosomethylbenzylamine (NMBA). There were no marked changes in protein expression in HEEC cells exposed to 2 or $10 \mu \mathrm{g} / \mathrm{ml}$ NMBA. Twenty-eight differentially expressed protein spots were identified in HEEC cells exposed to $50 \mu \mathrm{g} /$ ml NMBA. Two tumor suppressor proteins, prohibitin and c-Myc binding protein, were found to be down-regulated in NMBA-treated HEEC cells. S-adenosylhomocysteine hydrolase, a regulator of biological methylation, was found to be up-regulated in NMBA-treated HEEC cells. These findings may contribute to the further study of the molecular mechanism by which $\mathrm{N}$-nitrosamines promote esophageal carcinogenesis.
\end{abstract}

\section{Introduction}

N-nitrosamines are potentially carcinogenic to humans. Individuals are not only exposed to environmental $\mathrm{N}$-nitrosamines, but also to a wide range of precursors, which react in vivo to form endogenous $\mathrm{N}$-nitrosamines. A relatively high content of $\mathrm{N}$-nitrosamines has been detected in the diet and gastric juice of inhabitants from high incidence areas of esophageal cancer $(1,2)$. The excretion of $\mathrm{N}$-nitroso compounds

Correspondence to: Dr Yongen Xie, Institute of Immunology and Molecular Biology, North Sichuan Medical College, 234 Fujiang Road, Nanchong 637007, P.R.China.

E-mail: xyongen@sina.com

Key words: N-nitrosomethylbenzylamine, esophageal squamous cell, proteomics, esophageal carcinogenesis is also significantly higher in the urine samples of subjects from these areas (3). In addition, several N-nitrosamines, including $\mathrm{N}$-nitrosodimethylamine, N-nitrosodiethylamine and N-nitrosomethylbenzylamine (NMBA), have been shown to induce esophageal cancer in animal models $(4,5)$. These studies suggest that certain $\mathrm{N}$-nitrosamines are probable etiological factors for esophageal cancer. However, the exact role of $\mathrm{N}$-nitrosamines in esophageal cancer remains to be elucidated.

Recent advances in the field of molecular biology have facilitated the development of robust tools for uncovering interactions between pathogenic factors and host cells. Among these tools, proteomics is one of the most effective techniques. Proteomics is the investigation of the protein content or protein complement of the genome of a biological system, also termed the proteome (6). One of the objectives of proteomic research is to identify and describe the complex responses of a biological system to various stimuli. A vast amount of information may be obtained from one set of experiments as compared to the classic approach of observing concentration changes or modifications at the single protein level (7). Proteomic techniques have been widely used to disclose the mechanisms of disease. Numerous studies have analyzed the changes in protein expression between esophageal cancer and corresponding normal tissues (8-11), but little is known regarding changes in protein expression during the onset stage, when carcinogens begin to act on normal esophageal tissue cells. Changes in protein expression at this stage may be critical to uncovering the mechanism behind esophageal cancer.

In the present study, using two-dimensional electrophoresis (2-DE) and mass spectrometry (MS), we identified specific proteins whose expression differed in $50 \mu \mathrm{g} / \mathrm{ml}$ of NMBAtreated HEEC cells compared to normal HEEC cells. These findings may contribute to the further study of the molecular mechanisms by which $\mathrm{N}$-nitrosamines promote esophageal carcinogenesis.

\section{Materials and methods}

Cell culture and treatment. The human esophageal epithelial cell line HEEC was obtained from ScienCell Company (San 
Diego, CA, USA). Cells were seeded in poly-L-lysine-coated flasks containing EpiCM-2 medium, then cultured at $37^{\circ} \mathrm{C}$ in a humidified incubator with $5 \% \mathrm{CO}_{2}$. When the cells reached $50 \%$ confluence, NMBA was added to the culture for a final concentration of 2,10 or $50 \mu \mathrm{g} / \mathrm{ml}$. NMBA was not added to the control cells $(0 \mu \mathrm{g} / \mathrm{ml})$. When the NMBA-treated cells and the control cells reached $90 \%$ confluence, they were treated with trypsin solution and harvested by centrifugation. The harvested cells were seeded in new flasks, cultured and treated according to the above method until the fourth passage.

Protein preparation. Fourth passage cells were harvested and washed twice with ice-cold PBS. The cell pellets were incubated at $4^{\circ} \mathrm{C}$ for 30 min with cell lysis buffer containing $8 \mathrm{~mol} / \mathrm{l}$ urea, 4\% 3-[(3-cholamidopropyl) dimethylammonio]1-propanesulfonate (CHAPS), $40 \mathrm{mmol} / 1 \mathrm{Tris}$ and a mixture of protease inhibitors. After being sonicated briefly on ice, the samples were centrifuged at room temperature for $15 \mathrm{~min}$ at $12,000 \mathrm{rpm} / \mathrm{min}$ to remove insoluable materials. The protein in the supernants was further purified using the 2-D clean-up kit (Amersham, CA, USA). The protein concentration of the purified samples was determined by the Bradford method (12).

Two-dimensional electrophoresis. The first dimensional isoelectric focusing (IEF) was performed on a protein IEF cell system (Bio-Rad, CA, USA) using immobilized-pHgradient (IPG) strips (17 cm; pH 4-7). Protein (500 $\mu \mathrm{g}$ for analytical gels and $1.5 \mathrm{mg}$ for preparative gels) was used for IEF and subsequent second-dimensional electrophoresis. Protein samples were diluted to a final volume of $400 \mu \mathrm{l}$ with rehydration buffer containing $7 \mathrm{~mol} / \mathrm{l}$ urea, $2 \mathrm{~mol} / \mathrm{l}$ thiourea, 4\% CHAPS, $65 \mathrm{mmol} / 1$ dithiothreitol (DTT), 0.2\% Bio-Lyte and $0.001 \%$ bromophenol blue. IEF was performed at $17^{\circ} \mathrm{C}$ under the following conditions: $250 \mathrm{~V}$ for $25 \mathrm{~min}, 1,000 \mathrm{~V}$ for $2 \mathrm{~h}$ and $8,000 \mathrm{~V}$ for $5 \mathrm{~h}, 60,000 \mathrm{Vh}$ at $8,000 \mathrm{~V}$. After IEF, the IPG strips were maintained in equilibration buffer $(6 \mathrm{~mol} / \mathrm{l}$ urea, $20 \%$ glycerol, $2 \%$ sodium dodecyl sulfate, $0.375 \mathrm{~mol} / \mathrm{l}$ Tris- $\mathrm{HCl}$ buffer, $\mathrm{pH} 8.8$ ) with $2 \%$ DTT for $15 \mathrm{~min}$, and then in equilibration buffer with $2.5 \%$ iodoacetamide instead of DTT for $15 \mathrm{~min}$. The equilibrated strip was transferred to the surface of a $12 \%$ SDS-polyacrylamide gel and fixed with $1 \%$ low melting agarose in SDS-Tris-glycine running buffer with a trace of bromphenol blue. The second-dimensional separation was carried out using a Protean II XI system (Bio-Rad) with $12 \%$ SDS-PAGE gels (20 by $20 \mathrm{~cm}^{2}$ ), initially at $5 \mathrm{~mA}$ per gel slab for $30 \mathrm{~min}$, and then at $30 \mathrm{~mA}$ per gel slab, until the dye front penetrated to the bottom of the gel slab.

Gel staining and image analysis. The analytical 2-D gels were stained with silver nitrate and the preparative gels were stained with Coomassie Brilliant Blue R-250. Images of stained 2-D gels were captured using the Umax Power look 1120 scanner (Umax, P.R. China) in transmissive mode. Spot detection, quantification and matching were performed using PDQuest 7.2 software. Spot detection and matching between six gels (three from NMBA-treated cells and three from untreated cells) were performed automatically, followed by manual matching. The abundance of each protein spot was estimated by the percentage of volume, for example, individual spot volumes were normalized by dividing the optical density (OD) values of each spot by the total OD values of all the spots present in the gels, expressed as volume percentage. The significance of differences in the expression of the protein spots between NMBA-treated cells and untreated cells was estimated by the Student's t-test with significance set to a value of $\mathrm{P}<0.05$.

In-gel tryptic digestion, tandem mass spectrometry and database search. Protein spots of interest were manually excised from the preparative gels and de-stained with $25 \mathrm{mmol} / \mathrm{l}$ ammonium bicarbonate in $50 \%$ acetonitrile (ACN) for $20 \mathrm{~min}$ at room temperature. Subsequently, the spots were washed twice with de-ionized water and shrunk by dehydration in ACN. The dried gel spots were incubated in digestion solution consisting of $12.5 \mu \mathrm{g} / \mathrm{ml}$ proteomic grade trypsin and $25 \mathrm{mM}$ ammonium bicarbonate for $12 \mathrm{~h}$ at $37^{\circ} \mathrm{C}$. After trypsin digestion, peptides were extracted from the gel spots twice with $50 \%$ ACN and $0.2 \%$ trifluoroacetic acid (TFA) and dried in a centrifugal evaporator. The peptides were spotted on the target plate after elution with $0.8 \mu \mathrm{l}$ matrix solution $(5 \mathrm{mg} /$ $\mathrm{ml} \alpha$-cyano-4-hydroxy-cinnamic acid, $0.1 \%$ TFA, 50\% CAN), and then air-dried and analyzed using the 4700 MALDI-TOF/ TOF Proteomics Analyzer (Applied Biosystems) equipped with a 355-nm Nd:YAG laser. Proteins were identified by peptide mass fingerprinting (PMF) and tandem mass spectrometry (MS/MS) using the program Mascot v2.1 (Matrix Science, UK) against the NCBInr database with GPS explorer software (Applied Biosystems). Mascot protein scores >61 (based on combined MS and MS/MS spectra) were considered statistically significant $(\mathrm{P}<0.05)$.

Western blot analysis. To re-evaluate the expression of certain proteins identified in the NMBA-treated HEEC cells, Western blot analysis was performed. The protein samples were separated by $12 \%$ sodium dodecyl sulfate polyacrylamide gel electrophoresis and then transferred to nitrocellulose membranes (Millipore, MA, USA). Membranes were blocked by $0.05 \%$ Tween $20(\mathrm{v} / \mathrm{v})$ PBS containing $5 \%$ skim milk at room temperature for $3 \mathrm{~h}$, and then incubated with rabbit monoclonal antibodies against the identified proteins (Santa Cruz Biotechnology, CA, USA) and rabbit monoclonal $\beta$-actin antibodies (internal control antibody) at $4^{\circ} \mathrm{C}$ overnight. After three washes for $15 \mathrm{~min}$ in tris-buffered saline supplemented with $0.1 \%$ Tween-20, the membranes were incubated with an AP-linked goat anti-rabbit IgG secondary antibody (Santa Cruz Biotechnology) at room temperature for $2 \mathrm{~h}$. Finally, the membranes were reacted with NBT/BCIP reagents and washed with PBS once the protein bands had appeared. Densitometric analysis was used to calculate the relative expression level of the proteins.

Statistical analysis. Statistical analysis was performed by the Student's t-test. $\mathrm{P}<0.05$ was considered statistically significant. Statistical calculations were performed using the SPSS 10.0 statistical software package.

\section{Results}

Protein separation and image analysis. Protein samples isolated from the NMBA-treated and untreated HEEC cells 
A

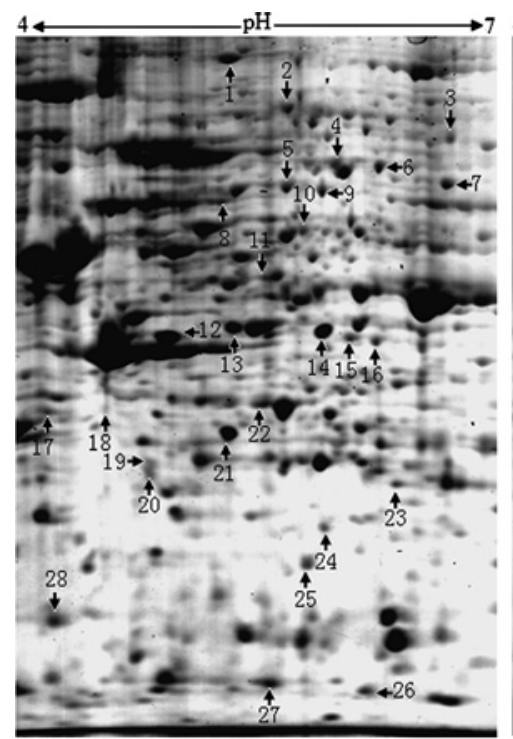

B

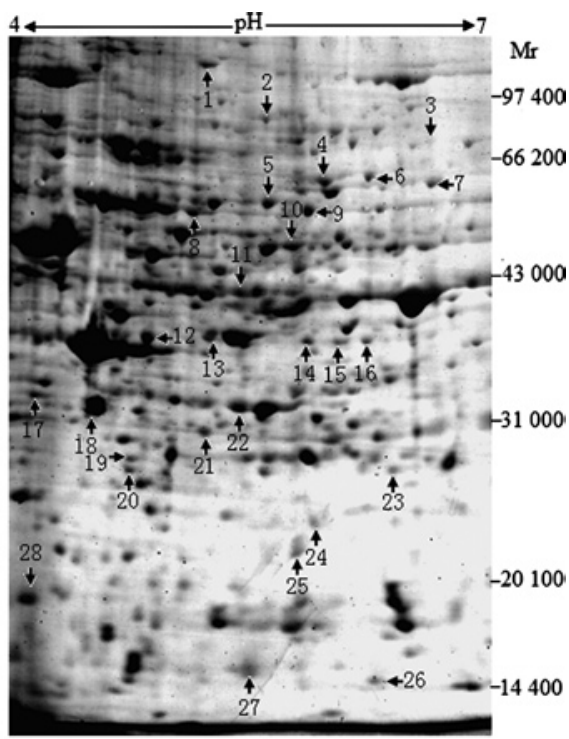

Figure 1. Representative two-dimensional (2-D) electrophoresis maps of the HEEC cells before and after NMBA induction. (A) 2-D map of untreated HEEC cells. (B) 2-D map of HEEC cells exposed to $50 \mu \mathrm{g} / \mathrm{ml}$ NMBA. Arrows and numbers show the differentially expressed protein spots. Nos. 4, 5, 8, 9, 10, 11, 17, $18,19,20,22$ and 28 show the up-regulated spots of HEEC cells exposed to $50 \mu \mathrm{g} / \mathrm{ml}$ NMBA. Nos. 1, 2, 3, 6, 7, 12, 13, 14, 15, 16, 21, 23, 24, 25, 26 and 27 show the down-regulated spots of HEEC cells exposed to $50 \mu \mathrm{g} / \mathrm{ml}$ NMBA.

were separated on duplicate 2-D gels, followed by SDS-PAGE analysis. Using PDQuest 2-D analysis software, the 2-D maps were analyzed and compared, and the abundance of individual protein spots on each gel was quantified. There were no marked changes in protein expression in HEEC cells exposed to 2 or $10 \mu \mathrm{g} / \mathrm{ml}$ NMBA (data not shown). Twenty-eight differentially expressed protein spots were identified in HEEC cells exposed to $50 \mu \mathrm{g} / \mathrm{ml}$ NMBA compared to untreated HEEC cells $(\mathrm{P}<0.05)$. Among these differentially expressed proteins, 16 were found to be down-regulated and 12 were found to be up-regulated. Representative 2-D maps of HEEC cells exposed to $50 \mu \mathrm{g} / \mathrm{ml}$ NMBA and untreated HEEC cells are shown in Fig. 1.

Identification of differential proteins by mass spectrometry. Eight spots were randomly selected from the 28 spots and identified by tandem MS. The identified proteins are shown in Table I and Fig. 2. Of the identified proteins, heterogeneous nuclear ribonucleo-protein $\mathrm{L}$, proteasome $\alpha 1$ subunit isoform1, ribosomal protein SA and S-adenosylhomocysteine hydrolase (SAHH) were found to be up-regulated, whereas eukaryotic translation initiation factor EIF3S2, prohibitin1 (PHB1), annexin A5 and c-Myc binding protein (MBP-1) were found to be down-regulated in the NMBA-treated HEEC cells compared to the untreated HEEC cells.

Confirmation of identified proteins. The differential expression of PHB1, MBP-1 and SAHH was confirmed by Western blot analysis. The expression of PHB1 and MBP-1 was significantly decreased in HEEC cells exposed to $50 \mu \mathrm{g} / \mathrm{ml}$ NMBA $(\mathrm{P}<0.05)$, but was not significantly affected in HEEC cells exposed to 2 or $10 \mu \mathrm{g} / \mathrm{ml}$ NMBA as compared to the untreated HEEC cells (Fig. 3). The expression of SAHH was significantly increased in HEEC cells exposed to $50 \mu \mathrm{g} / \mathrm{ml}$ NMBA, $(\mathrm{P}<0.05)$, but was not significantly affected in HEEC

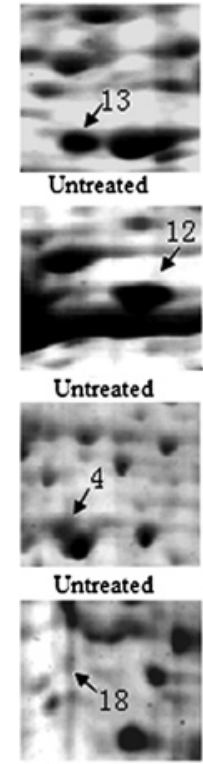

Untreated

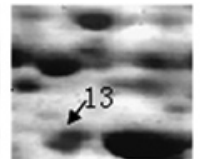
NMBA-treated
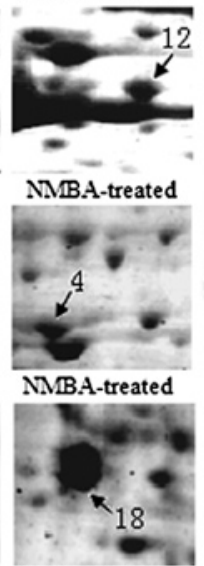

NMBA-treated
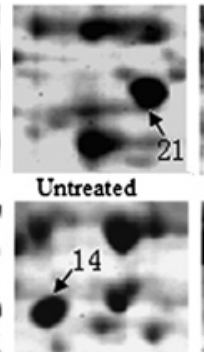

Untreated

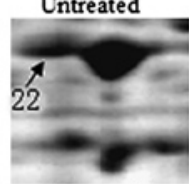

Untreated

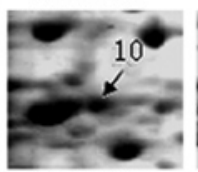

Untreated

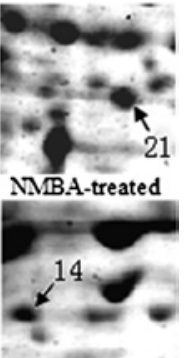
NMBA-treated

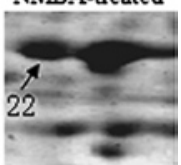

NMBA-treated

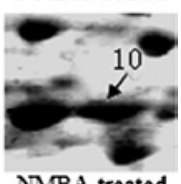

Figure 2. Magnified map of eight differentially expressed protein spots. Arrows and numbers indicate the differentially expressed protein spots. Spot numbers correspond to those shown in Fig. 1 and Table I.

cells exposed to 2 or $10 \mu \mathrm{g} / \mathrm{ml} \mathrm{NMBA}$ as compared to the untreated HEEC cells (Fig. 4).

\section{Discussion}

In this study, protein expression profiles were compared between NMB-treated human normal and esophageal squamous cells. Twenty-eight differentially expressed protein spots were identified in HEEC cells exposed to $50 \mu \mathrm{g} / \mathrm{ml}$ NMBA. Eight differentially expressed proteins were identi- 
Table I. Identified protein spots with differential expression between HEEC cells exposed to $50 \mu \mathrm{g} / \mathrm{ml}$ NMBA and untreated HEEC cells.

\begin{tabular}{|c|c|c|c|c|c|c|c|}
\hline \multirow[t]{2}{*}{ SSP no. ${ }^{\mathrm{a}}$} & \multirow[t]{2}{*}{$\begin{array}{l}\text { Protein } \\
\text { name }\end{array}$} & \multirow[t]{2}{*}{$\begin{array}{c}\text { NCBI } \\
\text { accession no. }\end{array}$} & \multirow[t]{2}{*}{$\begin{array}{l}\text { Theoretical } \\
\text { Mw (kDa)/pI }\end{array}$} & \multirow[t]{2}{*}{$\begin{array}{l}\text { Mascot protein } \\
\text { score }\end{array}$} & \multicolumn{2}{|c|}{$\begin{array}{l}\text { Spot volume } \\
\qquad(\%)^{\mathrm{b}}\end{array}$} & \multirow[t]{2}{*}{ P-value } \\
\hline & & & & & $\begin{array}{l}\text { Untreated } \\
\text { HEEC cells }\end{array}$ & $\begin{array}{l}\text { NMBA-treated } \\
\text { HEEC cells }\end{array}$ & \\
\hline $13(3509)$ & $\begin{array}{l}\text { Eukaryotic translation } \\
\text { initiation factor EIF3S2 }\end{array}$ & NP_003748 & $36478.6 / 5.38$ & 262 & $0.491 \pm 0.121$ & $0.122 \pm 0.049$ & 0.008 \\
\hline $21(3204)$ & Prohibitin 1 & NP_002625 & $29801.9 / 5.57$ & 571 & $0.686 \pm 0.078$ & $0.185 \pm 0.031$ & 0.000 \\
\hline $12(2401)$ & Annexin A5 & NP_001145 & $35902.4 / 4.94$ & 458 & $0.976 \pm 0.242$ & $0.413 \pm 0.154$ & 0.027 \\
\hline $14(6403)$ & c-Myc binding protein & AAA35698 & $36285.6 / 6.53$ & 312 & $0.754 \pm 0.048$ & $0.194 \pm 0.022$ & 0.000 \\
\hline $4(6803)$ & $\begin{array}{l}\text { Heterogeneous nuclear } \\
\text { ribonucleoprotein } \mathrm{L}\end{array}$ & NP_001524 & $64092.4 / 8.46$ & 350 & $0.147 \pm 0.047$ & $0.396 \pm 0.131$ & 0.037 \\
\hline $22(4302)$ & $\begin{array}{l}\text { Proteasome } \alpha 1 \\
\text { subuint isoform } 1\end{array}$ & NP_683877 & $30220.3 / 6.51$ & 216 & $0.186 \pm 0.030$ & $0.462 \pm 0.145$ & 0.032 \\
\hline $18(0301)$ & Ribosomal protein SA & NP_001012321 & $32833.4 / 4.79$ & 442 & $0.131 \pm 0.037$ & $1.090 \pm 0.238$ & 0.002 \\
\hline $10(5605)$ & $\begin{array}{l}\text { S-adenosylhomocysteine } \\
\text { hydrolase }\end{array}$ & NP_000678 & $47685.2 / 5.92$ & 181 & $0.233 \pm 0.037$ & $0.572 \pm 0.073$ & 0.003 \\
\hline
\end{tabular}

${ }^{a}$ The standard spot (SSP) numbers are unique numbers assigned to each spot in the MatchSet template by PDQuest software so that they are used in matching

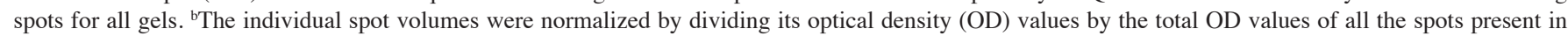
the gels. Data were shown as the mean $\pm \mathrm{SD}$.

A

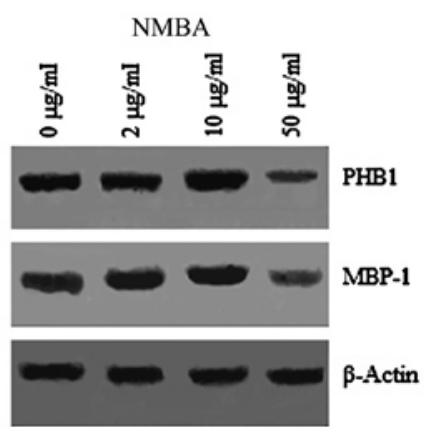

B

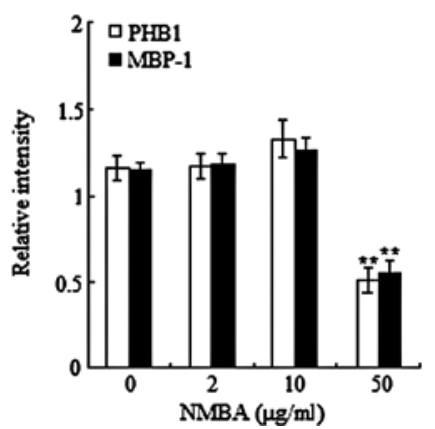

Figure 3. Expression of PHB1 and MBP1 in HEEC cells exposed to different concentrations of NMBA. Expression of PHB1 and MBP1 was detected by Western blot analysis. (A) Representative photograph of Western blot analysis. (B) Intensities of protein bands were quantified by densitometry. Equal protein loading was confirmed by exposure of the membranes to the anti- $\beta$-actin antibody. Data were normalized using the $\beta$-actin signal. Data are presented as the means \pm SD of three independent experiments. ${ }^{* *}$ Statistically significant difference in the expression of PHB1 or MBP1 in HEEC cells exposed to $50 \mu \mathrm{g} / \mathrm{ml}$ NMBA compared to the expression in control HEEC cells (cells exposed to $0 \mu \mathrm{g} / \mathrm{ml} \mathrm{NMBA}$ ), $\mathrm{P}<0.01$.

A

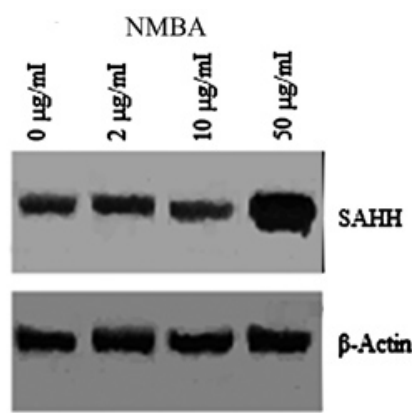

B

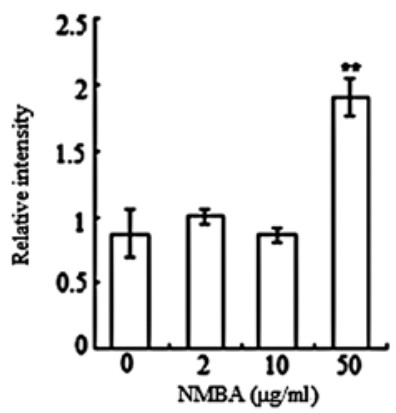

Figure 4. Expression of SAHH in HEEC cells exposed to different concentrations of NMBA. Expression of SAHH was detected by Western blot analysis. (A) Representative photograph of Western blot analysis. (B) Intensities of protein bands were quantified by densitometry. Equal protein loading was confirmed by exposure of the membranes to the anti- $\beta$-actin antibody. Data were normalized using the $\beta$-actin signal. Data are presented as the means \pm SD of three independent experiments. ${ }^{* *}$ Statistically significant difference in the expression of SAHH in HEEC cells exposed to $50 \mu \mathrm{g} / \mathrm{ml}$ NMBA compared to the expression in control HEEC cells (cells exposed to $0 \mu \mathrm{g} / \mathrm{ml} \mathrm{NMBA}$ ), $\mathrm{P}<0.01$. 
fied by MALDI-TOF MS. These proteins are involved in the regulation of cell signal transduction, cell proliferation, gene transcription, protein degradation and metabolic enzymes. It cannot be concluded that all of these proteins contribute to esophageal carcinogenesis, since changes in protein expression may also occur in HEEC cells suffering N-nitrosamine toxication. Among these proteins, three molecules, PHB1, MBP-1 and SAHH, may be involved in esophageal carcinogenesis.

PHB consists of two subunits, PHB1 and PHB2, and plays a role in mitochondrial protein folding, the regulation of cell cycle progression and transcription, the modulation of cell motility, and ligand binding at the plasma membrane (13). PHB was previously thought to be a negative regulator of cell proliferation and a tumor suppressor, but has now been shown to inhibit cell proliferation by repressing E2F-mediated transcription (14). Mutations in the human PHB gene or the 3' UTR of the PHB gene have been linked to sporadic breast cancer (15).

MBP-1 is produced by an alternative translation initiation site present on $\alpha$-enolase mRNA, but does not have glycolytic enzyme activity (16). The MBP-1 protein has been characterized as a $c-m y c$ oncogene promoter binding protein that negatively controls $c$-myc transcription $(17,18)$. MBP-1 was shown to play an important role in tumorigenesis, exerting a tumor-supressive effect on breast cancer and prostate tumors $(19,20)$.

SAHH is a ubiquitous enzyme catalyzing the hydrolysis of $S$-adenosyl- $L$-homocysteine (AdoHcy) to adenosine and homocysteine in mammalian cells. Inhibition of SAHH has been shown to result in the accumulation of intracellular levels of AdoHcy, which is a potent inhibitor of $S$-adenosyl$L$-methionine-dependent transmethylation reactions $(21,22)$. Up-regulation of SAHH may lead to the reduction of intracellular levels of AdoHcy and the hypermethylation of DNA. Promotor DNA hypermethylation is the key epigenetic mechanism by which tumor suppressor genes are inactivated in human cancer (23). The present results indicate that the up-regulation of SAHH may be critical to understanding the molecular mechanisms underlying N-nitrosamine-induced cancer.

Previous studies have demonstrated that N-nitrosamines do not directly affect gene expression, but rather are activated in host cells to form alkylating intermediates. These intermediates act on different sites of host DNA to change the expression of host genes $(24,25)$. In this study, we found that HEEC cells exposed low concentrations of NMBA showed no marked changes in protein expression. It is possible that a little NMBA entered into the HEEC cells, but hardly any alkylating intermediates were formed when the HEEC cells were exposed to low concentrations of NMBA.

In conclusion, this is the first study to identify changes in protein expression in human esophageal squamous cells before and after treatment with NMBA. Certain of these identified proteins may be involved in the carcinogenic action of nitrosamines on esophageal squamous cells. Further studies of these proteins may aid in elucidating the molecular mechanisms by which $\mathrm{N}$-nitrosamines promote esophageal carcinogenesis.

\section{Acknowledgements}

This study was supported by a grant from the Sichuan Youth Science and Technology Foundation, Sichuan, P.R. China (No. 08ZQ026-081). The authors thank Mr. Xin-wen Zhou for the help in MS analysis.

\section{References}

1. Lin K, Shen ZY, Lu SH and Wu YN: Intake of volatile $\mathrm{N}$-nitrosamines and their ability to exogenously synthesize in the diet of inhabitants from high-risk area of esophageal cancer in southern China. Biomed Environ Sci 15: 277-282, 2002.

2. Yang WX, Pu J, Lu SH, Li FM and Guo LP: Studies on the exposure level of nitrosamines in the gastric juice and inhibition in high risk areas of esophageal cancer. Chin J Oncol 14: 407-410, 1992.

3. Bartsch H, Ohshima H, Shuker DE, Pignatelli B and Calmels S: Exposure of humans to endogenous $\mathrm{N}$-nitroso compounds: implications in cancer etiology. Mutat Res 238: 255-267, 1990.

4. Baden T, Yamamichi K, Michiura T, Tsubura A and Hioki K: Sequential endoscopic findings and histological changes of $\mathrm{N}$-nitrosomethylbenzylamine-induced esophageal carcinogenesis in rats. Oncol Rep 16: 965-970, 2006.

5. Gurski RR, Schirmer CC, Kruel CR, Komlos F, Kruel CD and Edelweiss MI: Induction of esophageal carcinogenesis by diethylnitrosamine and assessment of the promoting effect of ethanol and N-nitrosonornicotine: experimental model in mice. Dis Esophagus 12: 99-105, 1999.

6. Wilkins MR, Sanchez JC, Gooley AA, Appel RD, Humphery-Smith I, Hochstrasser DF and Williams KL: Progress with proteome projects: why all proteins expressed by a genome should be identified and how to do it. Biotechnol Genet Eng Rev 13: 19-50, 1996.

7. Hirsch J, Hansen KC, Burlingam AL and Matthay MA: Proteomics: current techniques and potential applications to lung disease. Am J Physiol Lung Cell Mol Physiol 287: L1-L23, 2004.

8. Fu L, Qin YR, Xie D, Chow HY, Ngai SM, Kwong DL, Li Y and Guan XY: Identification of alpha-actinin 4 and $67 \mathrm{kDa}$ laminin receptor as stage-specific markers in esophageal cancer via proteomic approaches. Cancer 110: 2672-2681, 2007.

9. Hatakeyama H, Kondo T, Fujii K, Nakanishi Y, Kato H, Fukuda S and Hirohashi S: Protein clusters associated with carcinogenesis, histological differentiation and nodal metastasis in esophageal cancer. Proteomics 6: 6300-6316, 2006.

10. Du XL, Hu H, Lin DC, Xia SH, Shen XM, Zhang Y, Luo ML, Feng YB, Cai Y, Xu X, Han YL, Zhan QM and Wang MR: Proteomic profiling of proteins dysregulted in Chinese esophageal squamous cell carcinoma. J Mol Med 85: 863-875, 2007.

11. Jazii FR, Najafi Z, Malekzadeh R, Conrads TP, Ziaee AA, Abnet C, Yazdznbod M, Karkhane AA and Salekdeh GH: Identification of squamous cell carcinoma associated proteins by proteomics and loss of beta tropomyosin expression in esophageal cancer. World J Gastroenterol 12: 7104-7112, 2006

12. Bradford MM: A rapid and sensitive method for the quantitation of microgram of protein ultilizing the principle of protein-dye binding. Anal Biochem 72: 248-254,1976.

13. Theiss AL, Obertone TS, Merlin D and Sitaraman SV: Interleukin-6 transcriptionally regulates prohibitin expression in intestinal epithelial cells. J Biol Chem 282: 12804-12812, 2007.

14. Wang S, Zhang B and Faller DV: Prohibitin requires Brg-1 and Brm for the repression of E2F and cell growth. EMBO J 21: 3019-3028, 2002.

15. Jupe ER, Badgett AA, Neas BR, Craft MA, Mitchell DS, Resta R, Mulvihill JJ, Aston CE and Thompson LF: Single nucleotide polymorphism in prohibitin 39 untranslated region and breastcancer susceptibility. Lancet 357: 1588-1589, 2001.

16. Subramanian A and Miller DM: Structural analysis of alpha-enolase: mapping the functional domains involved in down-regulation of the c-myc protooncogene. J Biol Chem 275: 5958-5965, 2000.

17. Feo S, Arcuri D, Piddini E, Passantino R and Giallongo A: ENO1 gene product binds to the c-myc promoter and acts as a transcriptional repressor: relationship with Myc promoterbinding protein 1 (MBP-1). FEBS Lett 473: 47-52, 2000. 
18. Perconti G, Ferro A, Amato F, Rubino P, Randazzo D, Wolff T, Feo $\mathrm{S}$ and Giallongo A: The kelch protein NS1-BP interacts with alpha-enolase/MBP-1 and is involved in c-Myc gene transcriptional control. Biochim Biophys Acta 1773: 1774-1785, 2007.

19. Ray RB, Steele R, Seftor $E$ and Hendrix M: Human breast carcinoma cells transfected with the gene encoding a c-myc promoter-binding protein (MBP-1) inhibits tumors in nude mice. Cancer Res 55: 3747-3751, 1995.

20. Ghosh AK, Steele R and Ray RB: Carboxyl-terminal repressor domain of MBP-1 is sufficient for regression of prostate tumor growth in nude mice. Cancer Res 65: 718-721, 2005.

21. Shu S, Mahadeo DC, Liu X, Liu W, Parent CA and Korn ED: S-adenosylhomocysteine hydrolase is localized at the front of chemotaxing cells, suggesting a role for transmethylation during migration. PNAS 103: 19788-19793, 2006.
22. Schwerk C and Schulze-Osthoff K: Methyltransferase inhibition induces p53-dependent apoptosis and a novel form of cell death. Oncogene 24: 7002-7011, 2005

23. Karpf AR: Epigenomic reactivation screening to identify genes silenced by DNA hypermethylation in human cancer. Curr Opin Mol Ther 9: 231-241, 2007.

24. Leung KH and Archer MC: Mechanism of DNA methylation by N-nitroso(2-oxopropyl)propylamine. Carcinogenesis 6: 189-191, 1985.

25. Montesano R: Alkylation of DNA and tissue specificity in nitrosamine carcinogenesis. J Supramol Struct Cell Biochem 17: 259-273, 1981. 